University of Michigan Law School

University of Michigan Law School Scholarship Repository

Articles

Faculty Scholarship

2000

\title{
The Promise and Perils of Strategic Publication to Create Prior Art: A Response to Professor Parchomovsky
}

Rebecca S. Eisenberg

University of Michigan Law School, rse@umich.edu

Available at: https://repository.law.umich.edu/articles/1214

Follow this and additional works at: https://repository.law.umich.edu/articles

Part of the Business Organizations Law Commons, Intellectual Property Law Commons, and the Science and Technology Law Commons

\section{Recommended Citation}

Eisenberg, Rebecca S. "The Promise and Perils of Strategic Publication to Create Prior Art: A Response to Professor Parchomovsky." Mich. L. Rev. 98, no. 7 (2000): 2358-70.

This Correspondence is brought to you for free and open access by the Faculty Scholarship at University of Michigan Law School Scholarship Repository. It has been accepted for inclusion in Articles by an authorized administrator of University of Michigan Law School Scholarship Repository. For more information, please contact mlaw.repository@umich.edu. 


\title{
THE PROMISE AND PERILS OF STRATEGIC PUBLICATION TO CREATE PRIOR ART: A RESPONSE TO PROFESSOR PARCHOMOVSKY ${ }^{\dagger}$
}

\author{
Rebecca S. Eisenberg*
}

In a provocative recent article in the Michigan Law Review, ${ }^{1}$ Professor Gideon Parchomovsky observes that a firm racing with a competitor to make a patentable invention might find it strategically advantageous to publish interim research results rather than risk losing a patent race. This strategy exploits legal rules limiting patent protection to technological advances that are new and "nonobvious" in light of the "prior art" or preexisting knowledge in the field. ${ }^{2}$ By publishing research results, a firm adds to the prior $\operatorname{art}^{3}$ and thereby limits what may be patented in the future. Parchomovsky posits that, before it is able to claim a patentable invention of its own, a firm might have sufficient information to publish results that would raise the threshold for patentability enough to preclude the issuance of a patent to its rival. A firm that believes a rival is likely to complete an invention first might therefore try to defeat the rival's patent prospects through publication, leaving both firms free to compete in the market for the unpatented invention. Otherwise, the firm that wins the race could use the patent to exclude the lagging firm from the market entirely. This "spoiler" strategy, according to Parchomovsky, "explains the otherwise peculiar practice of commercial firms that routinely publish research results in scientific and technological journals." 4

One might question whether the widespread practice of publication can be taken as evidence that firms are pursuing a spoiler strategy of creating patent-defeating prior art in lieu of pursuing their own patent rights. Commercial firms might have other motivations for publi-

tC 2000 Rebecca S. Eisenberg. I am grateful to Marty Adelman, Doug Lichtman, and Ronald Mann for helpful comments on an earlier draft of this manuscript.

* Robert \& Barbara Luciano Professor of Law, University of Michigan Law School.

1. Gideon Parchomovsky, Publish or Perish, 98 MiCH. L. REv. 926 (2000).

2. 35 U.S.C. $\$ \S 102-103$ (1994 and Supp. 1999).

3. 35 U.S.C. $\S 102(a)$ bars issuance of a patent if "the invention was ... described in a printed publication in this or a foreign country, before the invention thereof by the applicant for patent." 35 U.S.C. $\$ 102$ (b) bars issuance of a patent if "the invention was ... described in a printed publication in this or a foreign country ... more than one year prior to the date of the application for patent in the United States."

4. Parchomovsky, supra note 1 , at 929. 
cation, such as gaining scientific recognition for their researchers and establishing credibility for their research results. These motivations can be particularly powerful in research-intensive industries. Access to top scientific talent may confer a competitive advantage on firms that permit their scientists to publish research results. Moreover, publication of promising results might make it easier for a firm to raise money for further research from investors or collaborators. Publication (typically after filing a patent application) might more typically mark a declaration of triumph in a race than an effort to contain the consequences of defeat.

But Parchomovsky does not attempt an empirical demonstration that firms, in fact, do publish research results to defeat the patent claims of their rivals. Rather, his mission is to illustrate how current doctrine might make this strategic maneuver attractive, and to suggest that patent policy should take this possibility into account. $\mathrm{He}$ attempts to illustrate the advantages of a preemptive publication strategy through a model that examines the possible payoffs confronting two pharmaceutical firms competing to invent a new drug. The plausibility of his analysis thus depends on the verisimilitude of the assumptions underlying the model.

Parchomovsky's model is vulnerable to two different lines of attack. First, it oversimplifies legal rules that, upon closer consideration, severely limit the circumstances in which a preemptive publication strategy would work. Second, the robustness of the model is further limited by its use of an optimistic hypothetical payoff matrix, in which preemptive publication leads to the sharing of only slightly reduced profits in a patent-free duopoly. In patent-dependent fields like drug discovery - the ostensible setting for Parchomovsky's model — firms would likely expect patent-free competition to be far more destructive of potential profits, minimizing its attractiveness. Preemptive publication might make sense for firms that would welcome lower competitive prices, but these are more likely to be prospective users of the invention than prospective sellers. Evidence of preemptive publication strategies at work in the field of genomics is consistent with this prediction.

Parchomovsky's analysis must contend with features of patent law that limit the circumstances in which a preemptive publication strategy would work. In order to understand these limitations, it is necessary to delve a bit more deeply into the role of "prior art" in patent doctrine. In evaluating an invention for patentability, U.S. law inquires into the state of knowledge in the field as of two different points in time: the invention date, ${ }^{5}$ and one year prior to the application filing

5. Three subsections of 35 U.S.C. $\$ 102-\S \S 102(\mathrm{a})$, (e), and (g) - define prior art as of the applicant's invention date. This focus on invention date as the moment for measuring prior art is consistent with a unique feature of the U.S. patent system: the allocation of pat- 
date. ${ }^{6}$ An invention may not be patented in the U.S. if it was disclosed in, or made obvious by, a publication prior to the applicant's invention date. $^{7}$ The invention date, however, may be earlier than the patent filing date. Faced with a publication that might bar the issuance of a patent, a U.S. patent applicant can sometimes get around the problem by proving an earlier invention date through a practice known as "swearing behind the reference." Even if, as Parchomovsky posits, the patent applicant had not yet completed the claimed invention as of the rival's publication date, the applicant may still avoid use of the reference as prior art by proving that, as of that date, the applicant had completed as much of the invention as the reference discloses. ${ }^{9}$ This rule generally prevents a lagging firm from defeating the patent claims of a leading firm by publishing interim research results that merely duplicate what the leading firm has already done.

There is one important limitation on the ability of patent applicants to avoid prior art references by proving earlier invention dates: an applicant may only swear behind a reference that is dated within one year of the application filing date. ${ }^{10}$ An applicant whose invention was disclosed in, or made obvious by, a publication dated more than one year before the filing date may not avoid the use of the reference as prior art, regardless of the invention date. ${ }^{11}$

These rules seriously limit the attractiveness of preemptive publication for the lagging firm in a race. If both firms are pursuing identical research paths, preemptive publication can only work if deployed at least a year prior to the application filing date of the leading firm. Otherwise, the leading firm could avoid the publication as prior art by proving that it had already progressed as far as the lagging firm as of the publication date. Put differently, the firm that is winning the race has one full year after the rival's publication date to file a patent appli-

ent priority to the first person to make an invention (rather than the first to file a patent application - the person who would prevail in most patent systems in the world).

6. Subsection (b) of 35 U.S.C. $\$ 102$ defines prior art as of one year prior to the application filing date. This provision has the effect of barring the issuance of a patent to a first inventor who waits too long to get a patent application on file after public disclosure or use of the technology.

7. See 35 U.S.C. $\$ \$ 102(a), 103$.

8. The procedural device for getting around the reference is known as a "Rule 131 affidavit." See 37 C.F.R. $\$ 1.131$ (1999). Rule 131 permits a patent applicant to overcome a patent or printed publication cited as prior art by proving completion of the invention prior to the effective date of the reference.

9. See In re Stryker, 435 F.2d 1340 (C.C.P.A. 1971); In re Stempel, 241 F.2d 755 (C.C.P.A. 1957).

10. If the date of the reference is more than one year prior to the patent applicant's own filing date, the applicant may not use a Rule 131 affidavit to swear behind the reference, see 37 C.F.R. $\$ 1.131(a)(1)$, and the reference will be available as prior art under 35 U.S.C. $\$$ 102(b) (1994 and Supp. 1999).

11. See In re Application of Foster, 343 F.2d 980 (C.C.P.A. 1965). 
cation before forfeiting the ability to swear behind the publication. If it takes more than a year for the firm that is ahead to cross the finish line after seeing the publication, that fact alone might call into question whether the publication made the invention obvious.

What if the two firms are not pursuing identical research paths, but rather, are taking different approaches toward the same inventive goal? In that case, the patent applicant may be unable to show that he had already completed as much of the invention as the publication discloses, limiting the risk that the applicant could avoid the effect of the reference by swearing behind it. But other factors might make publication more risky in this setting. If the information disclosed in the publication is news to the leading firm, disclosure of that information might accelerate its research efforts, perhaps even hastening the day when it is ready to file a patent application. At the very least, the patent applicant, having seen the publication, will enjoy a strategic advantage in drafting claim language that focuses on aspects of its own work that are distinguishable from the disclosures of the reference, and therefore still qualify for patent protection.

Publication of inadequate research results by a lagging rival might actually help the patent applicant to establish that the invention was nonobvious. The patent statute provides that an invention may not be patented if it would have been obviousness at the time it was made to a hypothetical practitioner of ordinary skill in the same field in light of the prior art. ${ }^{12}$ The strictness of this standard by its terms varies from one field to the next and changes over time, depending both on the scope and content of the prior art and on the prevailing level of skill among people working in the field. Rather than relying on hindsight reconstructions, courts routinely turn to evidence of actual events surrounding the making of an invention to shed light on determinations of nonobviousness, including evidence that the patent applicant succeeded where others had failed. ${ }^{13}$ By publishing research results that fall short of achieving a successful invention, a lagging rival thus risks helping the leading rival to prove patentability. Although the publication adds to the prior art, its limitations also help document that the ultimate solution to the research problem was far from obvious.

Another factor limits the strategic advantage of preemptive publication: often the publishing rival would be better off turning the same disclosure into a patent application of its own. As Parchomovsky recognizes, one need not actually succeed in making an invention work in the laboratory in order to patent it. The law merely requires that the applicant submit to the Patent \& Trademark Office ("PTO") an enabling disclosure that would permit a person of ordinary skill in the

12. 35 U.S.C. $\$ 103$.

13. Stratoflex, Inc. v. Aeroquip Corp., 713 F.2d 1530, 1538-39 (Fed. Cir. 1983). 
field to make and use the invention without undue experimentation. ${ }^{14}$ Filing a patent application that includes such an enabling disclosure is treated as a "constructive" reduction to practice, meaning that the invention will be considered complete as of the filing date. ${ }^{15}$ The same enablement standard that determines the sufficiency of a disclosure in a patent application also applies to publications cited as prior art. ${ }^{16} \mathrm{~A}$ publication that merely suggests a technological advance, without disclosing enough to allow a person of ordinary skill in the relevant field to make it without undue experimentation, cannot defeat a subsequent patent claim.

The requirement that a publication must be enabling in order to defeat a patent claim sets a high standard for preemptive publications, eliminating the possibility of making an invention obvious by publishing entirely speculative disclosures. At the same time, the possibility of relying on constructive reduction to practice in order to complete an invention sets a low threshold for filing a patent application, permitting a firm that knows what to do, but lacks the resources or patience to do the job itself, to patent an invention that it has not yet reduced to practice in the laboratory. ${ }^{17}$ In most cases, a firm positioned to publish an enabling disclosure that would make a subsequently claimed invention obvious would also be positioned to file a patent application claiming the invention as its own.

One situation in which it might be possible to create patentdefeating prior art, but not to file a patent application, is when the publishing firm can describe how to make an invention but does not yet know how to use it. A patent applicant must disclose a practical utility for an invention in order to get a patent, ${ }^{18}$ but it is not necessary for a publication to satisfy any utility standard in order to count as prior art. ${ }^{19}$ A publication that discloses a new chemical compound without describing what to do with it will prevent future patents from

14. See 35 U.S.C. $\S 112$ (1994 and Supp. 1999); Gould v. Hellwarth, 472 F.2d 1383 (C.C.P.A. 1973).

15. See Gould v. Schawlow, 363 F.2d 908 (C.C.P.A. 1966).

16. See Seymour v. Osborne, 78 U.S. (11 Wall.) 516 (1870); Rockwell Int'l v. United States, 147 F.3d 1358 (Fed. Cir. 1998); Motorola, Inc. v. Interdigital Tech. Corp., 121 F.3d 1461 (Fed. Cir. 1997).

17. This strategy only works if the patent applicant can also show conception of the invention, or a mental picture of what the invention looks like, as of the filing date. $C f$. Amgen v. Chugai, 927 F.2d 1200, 1216-17 (Fed. Cir. 1991) (holding that a patent applicant who made an enabling disclosure of how to clone a gene could thereby establish constructive reduction to practice of the invention, but could not establish conception of the gene as of the filing date when he did not yet know its structure).

18. See Brenner v. Manson, 383 U.S. 519, $534-35$ (1966); In re Brana, 51 F.3d 1560, 1564 (Fed. Cir. 1995).

19. See, e.g., In re Schoenwald, 964 F.2d 1122, 1124 (Fed. Cir. 1992) ("[N]o utility need be disclosed for a reference to be anticipatory of a claim to an old compound."). 
issuing on the compound itself, although a subsequent inventor who finds a use for it might be able to get a patent on a method of using the compound. In other words, when compounds are discovered before uses for the compounds are found, preemptive publication might allow a firm that is lagging in the race to identify uses to restrict the rival to patenting methods rather than patenting the compounds themselves. ${ }^{20}$ Although one might question whether this possibility is commercially significant, in fact compounds are routinely discovered before uses for the compounds.

In at least one context, the goal of creating patent-defeating prior art seems to be motivating, or at least accelerating, publication: contemporary genomics research. ${ }^{21}$ Scientists who identify novel DNA sequences before they understand their biological functions might create patent-defeating prior art through publication before they can satisfy the utility requirement necessary to claim their own patent rights in the sequences. ${ }^{22}$ The interaction of public disclosure with the patent system in this field has drawn much comment in accounts of the race between public and private sector efforts to complete the sequence of the human genome. ${ }^{23}$

The publicly funded Human Genome Project ${ }^{24}$ has made a fetish out of prompt disclosure of DNA sequence information, requiring grantees to deposit all newly identified DNA sequences and mutations in the publicly accessible Genbank database within twenty-four hours under the so-called "Bermuda rules."

20. See id.

21. The term "genomics" refers to the study of the DNA of different organisms.

22. The PTO is currently sorting its way through numerous patent applications on DNA sequences that push the limits of the utility requirement in this context. It recently published Revised Interim Utility Examination Guidelines, 64 Fed. Reg. 71440 (Dec. 21, 1999) corrected 65 Fed. Reg. 3425 (Jan. 21, 2000), and Training Materials for patent examiners on how to implement the guidelines with particular attention to examples from genomics and biotechnology. The training materials are available from the PTO website. See Revised Interim Utility Guidelines Training Materials (visited June 16, 2000) <http://www.uspto.gov/ web/offices/pac/utility/utilityguide.pdf; Revised Interim Written Description Guidelines Training Materials (visited June 16, 2000) <http://www.uspto.gov/web/offices/pad writtendesc.pdf $>$.

23. See, e.g., Eliot Marshall, Talks of Public-Private Deal End in Acrimony, 287 SCIENCE 1723 (2000); Justin Gillis, Gene-Mapping Controversy Escalates, WASH. POST, Mar. 7, 2000, at E1; Peter G. Gosselin \& Paul Jacobs, Clinton, Blair to Back Access to Genetic Code: The Two Leaders Plan to Issue Joint Statement That Data on Human Genome Should Be Public, Not Private, Property, L.A. TimeS, Mar. 14, 2000, at C1.

24. The Human Genome Project is an international effort to map and sequence all of the DNA in human cells. In the United States, its principal sponsors are the National Human Genome Research Institute and the Department of Energy. Numerous websites explain the goals and achievements of the Human Genome Project, including <http://www. nhgri.nih.gov/> and <http://www.er.doe.gov/>.

25. The Bermuda rules derive their name from an agreement entered into at the International Strategy Meeting on Human Genome Sequencing held in Bermuda in 1996. See David R. Bentley, Genomic Sequence Information Should Be Released Immediately and 
makes it difficult for grantees to get patent applications on file prior to public disclosure, much less to sort through newly identified sequences to determine whether any are worth patenting. Of course, prompt deposit of sequence information in the public domain can readily be justified, without invoking a patent-defeating strategy, as a way of giving the scientific community the benefit of free access to sequence information as quickly as possible. But other public statements from the National Human Genome Research Institute suggest a policy of preventing the issuance of patents on raw DNA sequence information within the Human Genome Project. ${ }^{26}$ Thus, public disclosure of DNA sequence information could indeed be an example of something like Parchomovsky's patent-defeating strategic behavior, although it remains to be seen whether it will be successful.

The sponsors of the Human Genome Project have somewhat different motivations than Parchomovsky attributes to his hypothetical lagging rival in a patent race. Rather than trying to preserve the option of competing in the market for unpatented products, these research sponsors claim to put DNA sequence information in the public domain in order to promote its widespread dissemination and use. The creation of patent-defeating prior art is a durable way of putting information in the public domain without having to worry that other institutions will obtain patents that remove it from public access.

Parchomovsky's analysis is more tantalizing as a way of explaining why some private firms have joined the government's efforts to publish DNA sequence information. As Parchomovsky might predict, it is often the laggards rather than the leaders among private firms involved in DNA sequencing races that sing the praises of the public domain and publish their research results without patents. Thus, for example, when Merck decided to sponsor the Merck Genome Initiative to generate partial gene sequences (expressed sequence tags

Freely in the Public Domain, 274 SCIENCE 533 (1996). The Bermuda rules have been criticized as promoting public disclosure of data that have not been checked for accuracy. See Mark D. Adams \& J. Craig Venter, Should Non-Peer-Reviewed Raw DNA Sequence Data Release Be Forced on the Scientific Community?, 274 SCIENCE 534 (1996).

26. This goal is manifest in the National Human Genome Research Institute's Policy on Availability and Patenting of Human Genomic DNA Sequence Produced by NHGRI Pilot Projects (visited June 19, 2000) <http:/www.nhgri.nih.gov/Grant_info/funding/statements/ RFA/intellectual-property.html>:

In NHGRI's opinion, raw human genomic DNA sequence, in the absence of additional demonstrated biological information, lacks demonstrated specific utility and therefore is an inappropriate material for patent filing. NIH is concerned that patent applications on large blocks of primary human genomic DNA sequence could have a chilling effect on the development of future inventions of useful products.... The grantees are reminded that the grantee institution is required to disclose each subject invention to the Federal Agency providing research funds within two months after the inventor discloses it in writing to grantee institution personnel responsible for patent matters. NHGRI will monitor grantee activity in this area to learn whether or not attempts are being made to patent large blocks of primary human genomic DNA sequence. 
or ESTs $)^{27}$ in the public domain, two other private firms already had a significant lead over the Merck-sponsored effort in generating private databases of ESTs. ${ }^{28}$ It is plausible that by putting ESTs in the public domain, Merck hoped to create prior art that would defeat future patent claims to the full-length genes corresponding to the ESTs, although it now seems unlikely that such a strategy will prove successful. ${ }^{29}$

The creation of patent-defeating prior art is an acknowledged part of the strategy of the SNP Consortium of private firms and a private foundation that are paying for university-based efforts to identify "single nucleotide polymorphisms" (SNPs), or single base-pair points of variation in the human genome..$^{30}$ Again, the SNP Consortium entered the race late, after numerous other SNP discovery efforts in the private sector were well under way. ${ }^{31}$. Under these circumstances, patent-defeating publication may be their best hope of preserving their future ability to use information that would otherwise become proprietary. But if the patent-defeating goal dominates the goal of prompt dissemination of information, prompt publication in the public domain may not be the best way to proceed.

In fact, the SNP Consortium, in contrast to the Merck Genome Initiative and participants in the Human Genome Project that comply with the Bermuda rules, does not publish all of its information as quickly as possible. Instead, it pursues a delayed publication strategy through the use of a patent law device called a Statutory Invention Registration, or SIR..$^{32}$ The SNP Consortium candidly describes its intellectual property strategy on its website as follows:

27. An expressed sequence tag or EST is a DNA sequence corresponding to a fragment of a gene, sufficient in length to make it unlikely that the same fragment occurs anywhere else in the genome. ESTs are created through a process that identifies only the small fraction of the genome of an organism that its cells are actually using (or "expressing") to produce proteins. The focus on expressed genes and the limitation to partial sequences permits the rapid creation of a database that tags those portions of the genome that are particularly likely to have biological (and commercial) importance. See Mark D. Adams, et al., Complementary DNA Sequencing: Expressed Sequence Tags and Human Genome Project, 252 SCIENCE 1651 (1991).

28. See Rebecca S. Eisenberg, Intellectual Property at the Public-Private Divide: The Case of Large-Scale cDNA Sequencing, 3 U. CHI. L. SCH. ROUNDTABLE 557 (1996).

29. Although the issue is not entirely free from doubt, it now seems unlikely that publication of an EST in the prior art would make the corresponding full-length gene obvious as that standard has been applied to patent claims to DNA sequences. See In re Deuel, 51 F.3d 1552 (Fed. Cir. 1995); In re Bell, 991 F.2d 781 (Fed. Cir. 1993).

30. Most of the members of the SNP Consortium are pharmaceutical firms. For a description of the SNP Consortium and its objectives, see The SNP Consortium, Ltd., The SNP Consortium - Full Genome Representative SNP Map Program Summary (visited June 18, 2000) <http://snp.cshl.org/about/program/html >.

31. See Eliot Marshall, Drug Firms to Create Public Database of Genetic Mutations, 284 SCIENCE 406 (1999); Eliot Marshall, Human Genome Project: 'Playing Chicken' Over Gene Markers, 278 SCIENCE 2046 (1977).

32. See 35 U.S.C. $\$ 157$ (1994 and Supp. 1999). 
The overall IP objective is to maximize the number of SNPs the [sic] (1) enter the public domain at the earliest possible date, and (2) to be free of third-party encumbrances such that the map can be used by all without financial or other IP obligations. To meet objective (2), the [SNP Consortium] intends to withhold public release of identified SNPs until mapping has been achieved to prevent facilitating the patenting of the same SNPs by third parties. Mapped SNPs will be publicly released quarterly, approximately one quarter after they are identified. The intellectual property plan is intended to maintain the priority dates of discovery of the unmapped SNPs during the period between identification and release, for use as "prior art." "33

The mechanism for creating prior art prior to public release of the SNPs is to disclose the information in a patent application that is subsequently converted to a SIR. This mechanism, which was added to the patent statute in $1984,{ }^{34}$ is codified at $\S 157$ of the Patent Act. It authorizes the Commissioner of Patents to publish, without prior examination for patentability, a statutory invention registration that meets the disclosure requirements of the patent statute ${ }^{35}$ if the applicant waives the right to receive a patent on the invention within a specified period of time. ${ }^{36}$ A SIR has the "attributes specified for patents," but does not include the right to exclude others from making, using, selling or importing the invention. ${ }^{37}$ Like a patent, a SIR is apparently effective as prior art in the U.S. as of its filing date, ${ }^{38}$ even though it might not be published for some time thereafter. ${ }^{39}$ In other words, it is possible to file a patent application that discloses a discovery, wait as long as the Commissioner will permit before converting it to a SIR, and then have the SIR count as prior art as of its filing date, just as if the application had been issued as a patent. This permits the creation of patent-defeating prior art while deferring disclosure.

33. The SNP Consortium, Ltd., supra note 30 (visited June 18, 2000) (emphasis added).

34. The Patent Law Amendments Act of 1984, Pub. L. No. 98-622, 98 Stat. 3383 (1984).

35. See 35 U.S.C. $\S 157$ (a)(1) (1994 and Supp. 1999).

36. See 35 U.S.C. $\S 157$ (a)(3) (1994 and Supp. 1999).

37. See 35 U.S.C. $\& 157$ (c) (1994 and Supp. 1999).

38. The basis for asserting prior art status for a SIR as of its filing date is the language of $\S 102(\mathrm{e})$ of the Patent Act, which precludes issuance of a patent on an invention that was "described in a patent granted on an application for patent by another filed in the United States before the invention thereof by the applicant for patent." 35 U.S.C. § 102(e). For an analysis of whether prior art status as of its filing date is among the "attributes" of a patent to which a SIR is entitled, see DONALD S. CHISUM, CHISUM ON PATENTS $\S 3.07[2]$ (2000).

39. The effectiveness of a SIR as prior art as of its filing date is limited to $\$ 102(\mathrm{e})$, which may be avoided by a patent applicant who can prove an earlier invention date. Once a SIR is published, it becomes effective as prior art under $\$ 102(b)$, which prevents the issuance of a patent on an invention that was "described in a printed publication ... more than one year prior to the date of the application for patent...." A rival who files a patent application within a year of the publication date of the SIR may thus avoid the prior art effect of the SIR by swearing behind its filing date. See supra notes 5-11 and accompanying text. 
Why would this strategy for the creation of prior art be preferable to Parchomovsky's preemptive publication strategy? Different institutions involved in genomics research may have compelling reasons for withholding research results from the public domain. How these reasons are balanced against the reasons for disclosure will vary depending on the priorities of the institution.

The foregoing discussion highlights one reason to withhold information from publication: public disclosure lets your rivals know exactly what you have accomplished and gives them the benefit of everything you have learned so far. This can be a problem for both publicly funded and private sector scientists and institutions involved in rivalrous research efforts, and it seems to be a concern on both sides of the race to complete the human genome sequence. The private firm, Celera, worried that competitors will repackage and sell their data, now contemplates imposing some commercial restrictions on use of the "free" version of the human genome sequence that they promised to make available upon completion..$^{40}$ The public sponsors of the $\mathrm{Hu}-$ man Genome Project have been equally worried about Celera's use of the information they have directed their grantees to make freely available under the Bermuda rules. For example, when Celera announced by press release that they had sequenced ninety percent of the human genome ${ }^{41}$ many people identified with public sector sequencing efforts were indignant that Celera had included DNA sequence data obtained from the Human Genome Project via the publicly accessible Genbank. Apparently, some representatives of the Human Genome Project are especially concerned that Celera's publications relating to the completion of the human genome sequence might include data deposited in Genbank by academic investigators who will not be listed as coauthors. ${ }^{42}$

In a rivalrous race to accumulate information, everything that a firm discloses in the public domain becomes available to its rivals and helps them get ahead. If one side makes their data freely available and the other keeps their data secret, the rival that relies on secrecy will always know at least as much as the rival that promptly discloses all data. Sometimes, the disclosed data will be of more value to the secretive rival than to the disclosing rival because of the cumulative value of combining data from the two sources. ${ }^{43}$ Prompt disclosure in

40. See J. Craig Venter, Clinton and Blair Shouldn't Destroy Our Research, WALl ST. J., Mar. 21, 2000, at A26.

41. Celera CORP., Celera Compiles DNA Sequence Covering $90 \%$ of the Human Genome (visited Jan. 10, 2000) <http://www.pecorporation.com/press/prccorp011000.html>.

42. See Eliot Marshall, Talks of Public-Private Deal End in Acrimony, 287 SCIENCE 1723 (2000).

43. Suppose, for example, that two rivals, Public University and Private Company, each sequence different portions of the same gene. Suppose further that the patent system offers more generous protection for full-length genes than for gene fragments. (Although the mat- 
the public domain can thus be treacherous if the ultimate goal is to avoid the issuance of future patents. On one hand, public disclosure creates potentially patent-defeating prior art. On the other, it may enhance the value of complementary private information and contribute to patent disclosures that will make it easier for rivals to obtain patents. The SNP Consortium tries to limit this problem by using SIRs to create patent-defeating prior art as of an earlier date than it makes public disclosures. This is an interesting tactical variation on Parchomovsky's preemptive publication strategy.

Filing patent applications is as good as publication from the standpoint of creating patent-defeating prior art, but it is superior from other perspectives. For one thing, by filing patent applications instead of posting or publishing their newly identified SNPs, the SNP Consortium avoids (or at least delays) adding to the proprietary SNP collections of other firms. Whatever information the Consortium discloses surely will be added instantaneously to the proprietary SNP collections, thus making them more complete. The SIR strategy also allows the Consortium to conceal from non-Consortium members what it has accomplished so far, creating uncertainty as to which of the SNPs that the proprietary rivals identify are worth patenting and which are already in the prior art. This increases patenting costs and may call into question whether patenting is worthwhile.

On the other hand, the SIR strategy does not make as much information available to the research community as quickly as does publication on a website. This may leave more people who seek prompt access to SNPs with nowhere to turn but proprietary collections. But, since the SIR strategy promises eventual disclosure, those institutions with less urgent needs for SNPs may be content to wait, knowing that they will soon be freely available. Delayed access may be good enough for the pharmaceutical firms in the SNP Consortium that hope to use SNPs in pharmacogenomic applications that are not

ter is not free from doubt, this appears to be consistent with the position of the PTO as reflected in recently disclosed training materials for patent examiners in applying the written description and utility guidelines. See Revised Interim Utility Guidelines Training Materials, supra note 22; Revised Interim Written Description Guidelines Training Materials, supra note 22.) If Public University freely discloses its portion of the gene in Genbank, Private Company might add that information to the partial sequence it already has, quickly complete the sequence for the full-length gene, and file a patent application that it could not have filed without the Public University disclosure. 
yet ready for practical implementation. ${ }^{44}$ It may be less satisfactory for researchers who want to use SNPs as soon as possible to find genes. ${ }^{45}$

If the goal of promoting prompt public access dominates the goal of defeating future patent claims, then publication might make more sense than filing. This may be one reason why the sponsors of the Human Genome Project, whose overarching mission is to promote research, call upon their grantees to deposit their data promptly in GenBank in accordance with the Bermuda rules rather than file patent applications and defer disclosure pending conversion to SIRs. But the public sector Human Genome Project has paid a price for this policy, which has advanced the competitive position of their private sector rivals in the race to complete the sequence of the human genome and may have enhanced their patent positions as well.

Although both the SNP Consortium and the Human Genome Project appear to be pursuing a strategy of prior art creation to limit future patents, neither is quite like the lagging rival in a patent race that Parchomovsky's model contemplates. The private pharmaceutical firms that belong to the SNP Consortium are more like potential customers than rivals of the firms assembling private databases of SNPs, and their motivation for defeating potential patent claims has more to do with future cost containment than with preserving their ability to participate in a future market as sellers. The same could be said of the public sponsors of the Human Genome Project, who are likely to be funding future research that builds upon knowledge of the human genome, and therefore want to keep the costs of access to this information down. These examples of strategic prior art creation thus do not demonstrate Parchomovsky's model in action.

There are reasons to suspect that the creation of patent-defeating prior art makes more sense for potential users of inventions than for potential sellers. Patents permit sellers to raise the costs of access to new technologies, a prospect that is generally more welcome to sellers than to buyers. From the perspective of would-be sellers of a new technology, the creation of patent-defeating prior art may seem more likely to destroy a lucrative market than to divide it. Parchomovsky's model blithely assumes that, if publication preempts patent protection, the two firms in a race would divide the market evenly, each enjoying duopoly profits totaling eighty percent of the profits that the winner would have obtained with a patent. ${ }^{46}$ This assumption seems highly

44. Pharmacogenomics involves the use of genetic markers to predict drug responses in individual patients on the basis of genetic differences. For a discussion of the use of SNPs in pharmacogenomics, see SNPs in Pharmocogenetics (visited May 23, 2000) <http://www.snps. com/pharm.html>.

45. For a discussion of the use of SNPs to find genes associated with susceptibility to disease, see Leslie Roberts, SNP Mappers Confront Reality and Find it Daunting, 287 SCIENCE 1898 (2000).

46. See Parchomovsky, supra note 1, at 937. 
implausible, at least as applied to Parchomovsky's example of the market for drugs. Pharmaceutical firms almost never invest in bringing unpatented new drugs to market, and the reduction in price and profits when generic manufacturers enter the field after a drug goes off patent is considerably greater than twenty percent. ${ }^{47}$ Perhaps the market for new drugs, involving high post-invention costs for clinical testing that make patent protection particularly important for new products, is idiosyncratic..$^{8}$ But surely there are many industries in which it would be difficult to maintain a lucrative duopoly in the absence of patent protection, calling into question the robustness of the model. ${ }^{49}$ If there are industries in which such a duopoly could be sustained without patents, they are likely to be industries in which patent protection is not particularly important, thus calling into question Parchomovsky's suggestion that his model might have normative implications for policymakers contemplating such issues as the correct nonobviousness standard.

It would make little sense to urge upon policymakers the normative implications of a strategic maneuver that no one actually uses. It is implausible that rival pharmaceutical firms seeking to develop a new drug would utilize preemptive publication, and the examples that I have identified of strategic prior art creation through publication in the genomics field have involved patent-defeating activities of wouldbe users, not sellers, of the contemplated inventions. Absent evidence that commercial rivals are actually deploying the strategy that Parchomovsky attributes to them, it seems premature to fine-tune doctrine to take such a possibility into account. For now, Parchomovsky's essay should be taken as an improvement on previously oversimplified patent race models, somewhat closer to reality than the models that preceded it, but by no means close enough to bear the weight of any suggestions for law reform.

47. Henry Grabowski and John Vernon have studied the change in price of brand name and generic drugs for drugs going off patent during the years 1984-1991. They found that two years after the first entry of a competing generic product, the price of generic products was on average $35-38 \%$ of the price of the corresponding brand name product, and the market share of the generics averaged $45-59 \%$, with generic products enjoying higher market shares in more recent years. See Henry Grabowski \& John Vernon, Longer Patents for Increased Generic Competition in the U.S.: The Waxman-Hatch Act After One Decade, 10 PHARMACOECONOMICS 110 (Supp. 2, 1996).

48. For a somewhat dated analysis of the costs of pharmaceutical research and development, see U.S. CONGRESS, OFFICE OF TECHNOLOGY ASSESSMENT, OTA-H-522, PHARMACEUTICAL R\&D: COSTS, RISKS AND REWARDS 47-72 (1993).

49. Parchomovsky acknowledges in a footnote that "the payoff of the competing firms from publication may be much lower than the duopoly profit," Parchomovsky, supra note 1 , at $937 \mathrm{n} .37$, but nonetheless he retains this counterfactual assumption as the basis for quantifying the payoff structure in his model. 